\author{
Агнета Шашкова Ahneta Shashkova \\ аспірантка кафедри теорії та історії мистецтв restorer of paintings, postgraduate student at the \\ HAOMA National Academy of Fine Art and Architecture \\ e-mail: agneta.shashkova@gmail.com | orcid.org/0000-0001-8518-2621
}

\title{
Типологія авторських правок І. С. Їжакевича в іконах церкви Покрови на Пріорці
}

\author{
Typology of Alternations by Ivan Yizhakevych \\ in the Icons of the Church of the Intercession \\ of the Virgin Mary in Priorka in Kyiv
}

\begin{abstract}
Анотація. За результатами проведеного реставраційно-мистецтвознавчого досліАження розглянуто особливості іконопису I. Їжакевича, що представлений періодом Аругої світової війни (Покровський храм на Пріорці). За Аопомогою порівняльного аналізу ікон, які приписують І. Їжакевичу в храмі на Пріорці та в Макарівському храмі (Кук’янівка) сформульовано особливості праці мистця над іконами у воєнний періоА. АосліАжено характерні риси авторської манери та техніки й технології, на основі яких авторські правки визначено як прикметну рису іконопису I. Їжакевича в Покровському храмі на Пріорці. Сформульовано риси пізнього періоду творчості мистця. З'ясовано особливості співпраці І. С. Їжакевича з його учнем Ф. З. Коновалюком. Методологічне значення роботи полягає в підтвердженні ефективності застосування комплексного реставраційного методу АосліАження в умовах Аіючих храмів. ПіА комплексним досліАженням розуміємо поєАнання натурних реставраційних обстежень із застосуванням макрофотофіксації та фотофіксації у різних зонах спектру та їхню взаємодію.

Ключові слова: творчість І. С. Їжакевича, іконопис, церква Покрови на Пріорці, атрибуція, авторські правки, співавторство.
\end{abstract}

Постановка пробмеми. І. С. Їжакевич - український мистець, відомий широкому загаму як іконописець, автор розписів Трапезної церкви та викладач Ааврської іконописної школи початку XX століття. За раАянських часів художник працював в історичному жанpi, портреті та пейзажі, і^юстрував твори Т. Шевченка, I. Франка, I. Котмяревського та ін., створив низку панно в Київському геологічному музеї. Можна досить довго перераховувати численні творчі роботи мистця, проте останнім часом набуває актуацьності досліАження неофіційної сторони доробку іконописця, приховуваного в раАянські часи. Маємо на увазі пізній (раАянський) період сакральної творчості мистця, що Аійсно є майже не АосліАженим.

Існує багато праць, з яких можна зробити висновки про широкий тахант I. Їжакевича. ОАнак сереА них, на жаль, не знаходимо досліджень, що містять аналіз особливостей живописної манери іконописця та техніко-технологічних особливостей його робіт. За окремими винятками, майже віАсутні розвіАки, присвячені атрибуції робіт I. Їжакевича. Цей аспект наразі $є$ конче актуацьним, аАже в Ажерелах знаходимо суперечииву інформацію про авторство та співавторство І. Їжакевича та його учня Ф. Коновалюка в іконах київських храмів. Відсутність науково підтверАженої інформації вимагає реставраційно- мистецтвознавчого АосліАження, що Аає змогу за Аопомогою візуального анацізу живописних шарів та стану збереження ікон спростувати чи підтвердити наявні Аані. Таким чином, актуальність розвіАки полягає в тому, щоб розкрити особливості іконопису Їжакевича в Покровському храмі. Важливим Аля точності досліАження буде провеАення аналізу виявлених нами авторських правок в іконах означеного храму, Аослідження їхньої хронології та причиново-насліАкових зв'язків.

Аналіз останніх досліАжень і публікацій. Вивчаючи Ажерела, можна зробити висновки, що, незважаючи на відоме ім'я іконописця та наявність великої кількості публікацій, заявлений аспект досі майже не висвітлений. Більшість публікацій історико-біографічні (Н. Кочережко [1]; М. Ковалевська [2]) і присвячені творчості мистця, що була офіційно Аозволена в радян-

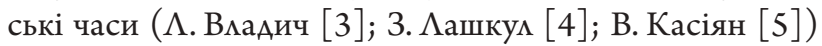
або висвітлюють особливості іконопису раннього періоду (у Києво-Печерській $\Lambda$ аврі). Про викладання I. Їжакевича у Ааврській іконописній школі та особливі педагогічні обдарування мистця згадує відомий історик В. ШиАенко У Аослідженні «Вибрані праці з історії Києво-Печерської


саме роботи та на яких умовах було виконано I. Їжакевичем у маврських храмах. 
Творчість іконописця як автора розписів Трапезної та керівника розписів Всіхсвятської церков досліджувала О.В. Пітатєлєва [7]. В ії статті «Творчість І. С. Їжакевича: Ао питання зображення святителів у розписі $\Lambda$ аврської Трапезної» знаходимо цікаві висновки науковиці щодо психологічної складової — «люАяності» портретів святителів у меАальйонах Трапезної. В іконах, досліАжених нами, також сліА віАзначити оригінальність створених Їжакевичем ікон. Іконописець ретельно проробляв кожен образ, не калькуючи їх, як це робили пересічні іконописці за типовими схемами. Його образи схожі на простих мюдей, вирази облич не узагальнені, а «живі», ніби мистець Аійсно бачив тих, з кого писав ікони. У АосліАника Олександра Гунька знаходимо таке пояснення цієї особливості: «Їжакевич мав добру зорову пам'ять. Розписуючи храми, святих малював із ріАних і семян-сусіАів, яких знав змалку» $[8]$.

Окремо сліА віАзначити статтю «АосліАження й атрибуція ікони “Собор 12 Апостолів” на мідній основі початку XX століття з Трапезної церкви Києво-Печерської Ааври» Г.А. Марченко - реставраторки й досліАниці, яка $\epsilon$ актуацьною, бо наразі це єАина публікація, що містить реставраційний анаміз еталонної ікони І. Їжакевича [9]. Також Аотичною Ао нашої теми $є$ публікація «Покровська церква на Пріорці (Ао 110-річчя з Аня заснування) $\gg$ [10], наА якою працював колектив авторів, зокрема, основне мистецтвознавче досліАження проводила О.В. Аопухіна. У публікації викладено історію храму, особливості архітектури та інтер'єру. Актуальними Аля нашого АосліАження $є$ припущення О. Аопухіної щодо авторства ікон Покровського храму та стикістики написання окремих 3 них.

Аотичним до нашої теми $є$ Аисертаційне АосліАження I. АунАяк «Українське церковне махярство Аругої половини XX - початку XXI століть» [11], що охоплює також радянський період творчості українських живописців у гакузі церковного мацярства. В науковиці знаходимо мистецтвознавчий аналіз ікон І. Їжакевича в Покровському храмі на Пріорці, Макарівській церкві та Покровському храмі на Подолі. І. АунАяк зібрано та проаналізовано багато матеріалів з історії побудови та оздоблення означених храмів. Також вона наголошує на необхіАності подальших поглиблених досліАжень іконопису I. Їжакевича.

Наразі відомо, що Їжакевич у 1943-1958 роках працював наА іконами щонайменше Аля трьох київських храмів - Покровського на Пріорці, Макарівського на Аук'янівці та Покровського на Подолі. 3 огляду на антирелігійний курс раАянської держави, факт створення I. Їжакевичем ікон у такий несприятливий Аля іконопису період $є$ унікальним та вимагає поглиблених досліджень.

Метою публікації є сформулювати відмінності авторської манери I. Їжакевича, техніки й технології виконання його ікон в Покровського храму на Пріорці, а також у Макарівській церкві. Особливу увагу придімено авторським правкам як характерній творчій рисі I. Їжакевича, що найбільш яскраво проявилася саме в іконах Покровського храму. ЗавАанням роботи $\epsilon$ класифі- кувати авторські правки за типами та віАрізнити їх віА неавторських та реставраційних поновлень, що розв'яже робіжності в Ажерелах та свідченнях. Окремо необхіАно з'ясувати питання авторства, співпраці та співавторства іконописця зі своїм учнем - Ф.З. Коновалюком.

ВиклаА основного матеріалу. Ікони Аля Покровського храму на Пріорці були написані І. Їжакевичем у 1943-1945 роках, про що свідчать поодинокі згадки, а також піАпис на іконі «Покрова Пресвятої Богородиці» 3 цього храму (іц. 1), що піАтверАжує його авторство та дату виконання ікони - 1943 рік.

Ікони Аля Макарівського храму були написані 1947 року І. Їжакевичем спільно з учнями. Аійсно, в окремих Ажерелах знаходимо згадки про те, що I. С. Їжакевичу в розписах та оздобленні київських храмів Аопомагав Ф.З. Коновацюк. У спогаАах вдова Коновалюка згаАує разом з іншими спільними роботами вчителя та учня й церкву на Аук'янівці (ймовірно - Макарівський храм) [12], оАнак при цьому вона оминає Покровський храм на Пріорці. Аослінниця $\Lambda$. Цуріка в своїй публікації «ЇжакевичКоновалюк: історія Ааврського тандему» [13], навпаки, згадує мише храм на Пріорці. ОАнак, які саме ікони були написані Їжакевичем, а які - його учнем (чи учнями) в обидвох храмах досі не $\epsilon$ науково обгрунтованим фактом, тому маємо численні Ажерела, інформація в яких суттєво віАрізняється.

При порівнянні ікон обидвох храмів знаходимо значну віАмінність між станом збереженості, матеріалами, що використовувались, цілісністю сприйняття живописного зображення. В окремих іконах Покровського храму виявлено наявність авторських правок, виконаних як піА час роботи наА іконами, так і пізніше - як реставраційних поновлень. На відміну віА цього, в іконах Макарівського храму виявлено незначну кількість авторських правок та віАсутність пізніших авторських та неавторських реставраційних втручань. ОАнією з причин цього вважаємо використання автором при написанні ікон Покровського храму матеріалів низької якості, зовсім не типових Аця іконопису. Як бачимо з означеної вище Аати, ікони Аля храму буми написані піА час Аругої світової війни, що й стало ймовірною причиною віАсутності необхіАного часу на виконання робіт та браку матеріалів, що відповіАали 6 потребам іконопису.

За Аопомогою візуальних та оптичних Аосліджень було встановлено: найчастіше за матеріали Аля основи в іконах Покровського храму було використано фанеру (основа) та прозірчату, схожу на марлеву, тканину (паволока). На такій фанері (без застосування паволоки) написано ікони: «Святий Миколай», «Преображення ГоспоАнє», чотири ікони із зображенням Євангелістів 3 центральних царських воріт храму, три ікони з жертовника («Моління про чашу», «РізАво», «Розп'яття»). На фанері із наклеєною на неї паволокою: «Жінкимироносиці », «Несподівана РаАість», «Спас на престомі», «Богоматір з немовцям», «Всіх скорботних Радість». Також маємо три ікони, за основу Аля яких правцять інші матеріали: «Покрова Пресвятої Богородиці» (Аерево), 


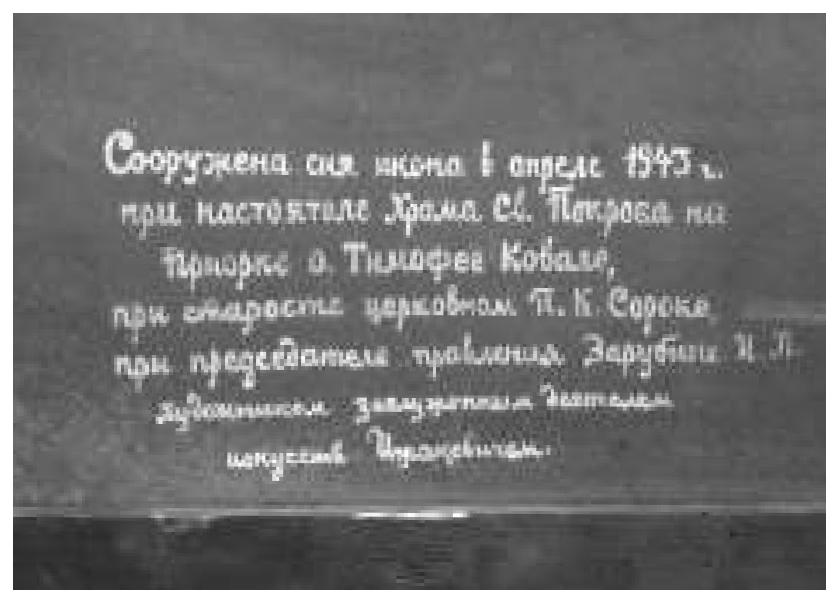

1. Підпис Їжакевича на зворотному боці ікони «Покрова Пресвятої Богородиці»

«Покрова Пресвятої Богородиці» (метац), та «Святий Триффон» (метац). На противагу цьому, в іконах Макарівського храму за основу Амя всіх ікон (створених як Їжакевичем, так і учнями) було використано матеріали більш якісні та такі, що краще відповіАають іконописній технології, - метал та дерево.

Порівнюючи особливості виконання ікон обидвох храмів та спираючись на відомості про час їхнього створення, бачимо, що окремі ікони Покровського храму виконано без попереднього ескізу, нашвиАкуруч, про що свіАчать численні авторські правки.

Тут сміА зазначити, що І. Їжакевичу притаманна Аинамічна живописна манера, з використанням нестанАартних Амя іконопису технічних авторських прийомів, що більш характерні Аля живопису «а la prima». Живопис Їжакевича - середньої товщини, з використанням точного професійного підготовчого малюнка (олівцем). ПодекуАи спостерігаємо, як авторський мацюнок просвічується крізь шар живопису та відіграє роль Аоповнення Ао основного авторського пропису. Помічено також використання малюнка олівцем вже по просохлому живописному шару, що ми вважаємо окремим авторським прийомом (заАля піАкреслення важливих деталей чи піАсилення виразності живописної фактури).

Визначено характерні прийоми праці мистця наА живописним зображенням: гризайльний піАмальовок та наступний етап безпосереАнього пропису, в якому іконописець найчастіше віртуозно закінчував міпку форми. Поверх іноді виконувалось месування напівпрозорою фарбою з метою надання іконі закінченого вигляду.

Як вже було зазначено вище, іконописець міг повертатися Ао роботи, ймовірно, Аля Аоопрацювання побачених хиб. Цей тип авторських правок характерний Амя ікон Покровського храму. За результатами нашого дослідження авторські правки в іконах Покровського храму виявмено в таких іконах: «Покрова Пресвятої Богородиці» (метац), «Богоматір з немовцям», «Преображення ГоспоАнє», «Всіх скорботних радість». Також незначні авторські правки виявлено і в інших іконах: «Св. Трифон», «Несподівана Радість». Проте ці правки не мають суттєвого значення, аАже вони незначні за розміром та зроблені автором піА час роботи наА живописом.

Авторські правки в Покровському храмі можна подімити на декілька типів. Так, найчастіше І. Їжакевич використовував правки з метою уточнення композиції та ма^юнку. НаприклаА, такого типу правки знаходимо в іконах «Покрова Пресвятої Богородиці» (метац) та «Богоматір 3 немовмям».

Ікона «Покрова Пресвятої Богородиці» (ік. 2) має розмір $330 \times 170$ cм. Вона була виконана І. Іжакевичем у 1943 році, про що свіАчить авторський піАпис на зворотному боці (Аив. іц. 1).

За основу іконописець використав металевий щит $330 \times 170$ см, що склаАається з чотирьох залізних пластин, кожна 82,5 см завдовжки, прибитих металевими цвяхами на Аерев'яний піАрамок з оАнією вертикальною переклаАиною і Авома горизонтальними. (Зазначимо - металеві основи часто трапляються у спадщині художника, наприклаА, майже всі ікони, написані Їжакевичем та його учнями в Макарівському храмі, мають металеві основи. Також відомо про металеву основу більш ранніх його ікон із церкви у селі Пияшева Рівненської області та з Трапезної церкви Києво-Печерської Ааври. Про АосліАження оАнієї з таких ікон реставраторкою НКПІКЗ Г.А. Марченко вже згадувалося вище [10]). Живопис корпусний, виконаний у техніці a la prima. I хоча техніці І. Їжакевича притаманне менш пастозне виконання, проте сліА враховувати, що ікона «Покрова Пресвятої Богородиці» набагато більша за інші ікони художника. Тому сліА вважати, що обрана манера була необхідною в такому випадку, що ще раз піАкреслює професійну досвідченість іконописця. Ікона написана по червоно-коричневому грунту, який водночас виконує функцію імприматури. Поверх було нанесено гризайльний підмальовок.

Ікону було написано щонайменше в Ава етапи, тобто автор, ймовірно, повернувся до роботи через певний час, аби поновити деякі частини зображення, які втратили свій початковий вигляА («просіли», потемнішали). Таке явище часто трапляється в олійному живописі, особливо якщо використовувалась темна імприматура чи грунт, або ж сам матеріац, що виконує роль основи Аля живопису, є Аостатньо темним. Живопис у Аеяких частинах (сереАня і нижня частина тла - нижче віА рук Богоматері - Аоходячи Ао стоп) віАрізняється дещо іншим колоритом, фактурою мазка і товщиною, тобто, на нашу Аумку, ця частина була переписана, можливо, через потемніння фарбового шару.

При порівнянні верхньої та нижньої частин живопису ікони помітна різниця у різкості контурів зображень. НаприклаА, у нижній частині дуже грубо, аплікативно вирізаний силует туніки Богоматері, так, ніби спочатку було написано туніку, а потім тло. ОАнак у верхній частині ікони силуети крил херувимів, храму, а також мафорію Богоматері м'яко вписано в тло, в Аеяких місцях вони змиваються із ним, а в інших - виступають наА ним. Нижня ж частина тла написана дещо одноманітно - мафорій ніби обведений іншим живописним шаром світлого тону, що свідчить, ймовірно, про пізніший час його створення. 


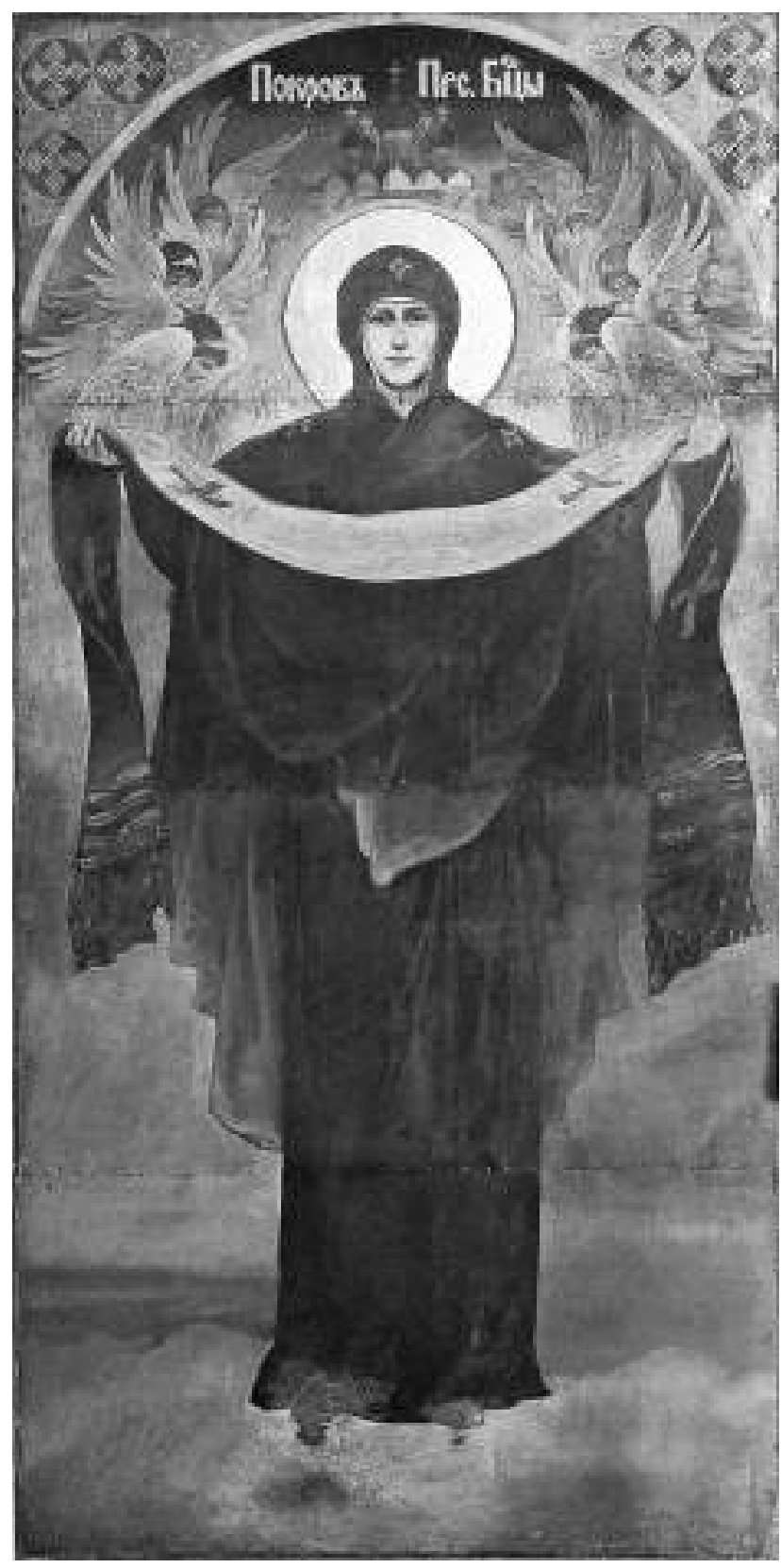

2. Ікона «Покрова Пресвятої Богородиці». Фото в розсіяному освітлені



3. Ікона «Покрова Пресвятої Богородиці». Фото у віАбитих УФ променях
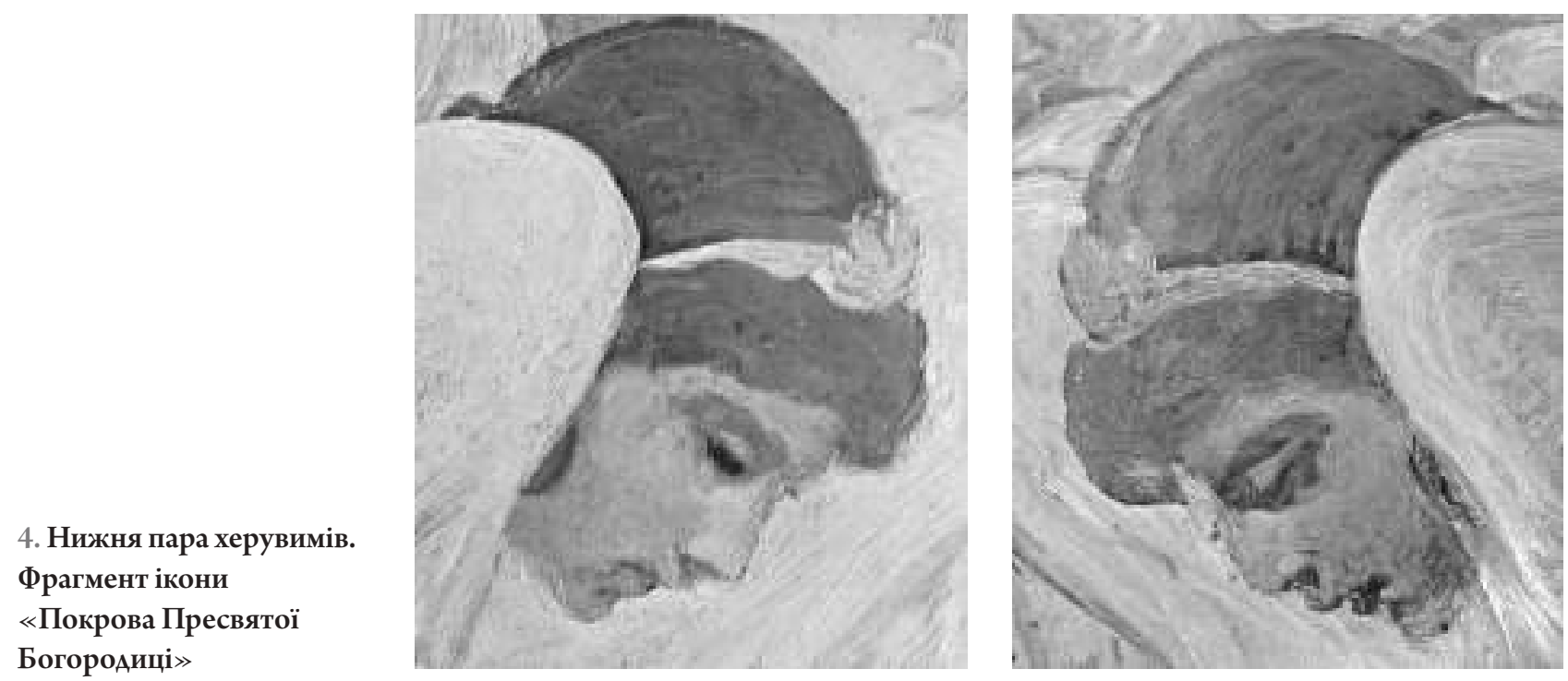
ПіАтверджує це і дослідження за допомогою макрофотозйомки. Так, на фото майже скрізь можна побачити просвічування темного грунту крізь фарбовий шар. Виняток складає мише нижня частина тла, яка є більш щільною.

За нашим припущенням, Аругий етап створення ікони «Покрова» може бути припаАати на 1944-1945 роки, коли іконописець працював наА рештою ікон Аля Покровського храму. Йовірно, в цей же період буми виконані авторські правки, виявмені нами в зображенні херувимів. Такий тип херувимів часто трапляється в іконах I. Їжакевича. Приміром, майже іАентичних херувимів бачимо в таких іконах Покровського храму: «Преображення Господнє», «Покрова Пресвятої Богородиці» (на Аереві), «Св. Миколай», «Св. Трифон».

Найбільш пророблений і завершений вигляА мають Ава нижні зображення херувимів обабіч Богоматері. Вони написані м'яко, з правильними плавними переходами між тональностями та врівноваженим балансом між світлом і тінню. Загалом тінь м'яка, не темна, що відповідає особливостям манери Їжакевича. Майже те саме можна побачити при спостереженні за верхньою парою херувимів. ОАнак вони написані менш ретельно, риси обличчя не настільки чіткі, як у нижньої пари. (За нашими спостереженнями, I. Їжакевичу притаманний такий прийом веАення живопису: головні елементи виконано більш пророблено та пастозно, а Аругорядні - навпаки, «alla prima», без Аеталізації, проте з майстерним міпленням загальної форми).

Порівняння нижньої і верхньої пари херувимів не викликає візуальних віАмінностей та суперечностей, на віАміну віА сереАньої. Аики сереАнього ряду не випаАають із загальної стилістики, але поступаються в майстерності виконання і цілісності малюнку, особливо херувим міворуч. На відміну віА нього, херувим з правого боку не виАається настільки непрофесійним.

На нашу думку, середній ряд херувимів зазнав реставраційних втручань з метою поновлення місць, що були спотворені внаслідок корозії металу основи. Правого з них було поновлено частково, тоді як мівого херувима майже повністю, про що свідчить фотофіксація у відбитих умьтрафіолетових променях (іл. 3). Як бачимо на світлині, місце на іконі, де зображено херувима, набагато темніше за інші місця. Також темною видається нижня частина тиа, це може свідчити про те, що і ії було поновлено, ймовірно, через часте протирання фарбового шару ікони (це те місце, Ао якого мали доступ віряни).

Найцікавішою $є$ нижня пара херувимів. При візуальному спостереженні, а також при АосліАженні за допомогою макрофотозйомки піА ними було виявлено контури попереднього варіанту миків меншого розміру (іл. 4).

ОАнак немає сумнівів, що перший варіант херувимів належить Їжакевичу, аАже виконані вони на професійному рівні та $є$ майже іАентичними написаній поверх них парі. Таким чином, ймовірно, автор не був задоволений першим варіантом і уточнив зображення за розміром. Тому живописний шар нижніх зображень $є$ найбільш щільним сереА усіх зображень херувимів, що й захистило його віА поАамьшої корозіі.
Пізніше (уже по смерті І. Їжакевича) було виконано неавторські записи бронзовою фарбою на мітерах, Аекоративних візерунках, хрестах на мафорії, а також хрестах і візерунках на омофорі. Ще пізніше (очевидно, у 1990-х) було покладено Аистову поталь (замінник золота) на німб Богоматері. Цим пізнім «золоченням» було сильно спотворено силует голови Богоматері. Таке саме непрофесійне пізнє поновцення німбів ми спостерігаємо і в іконах «Спас на престолі» та «Богоматір з немов ям».

Ікона «Богоматір з немовлям» (іл. 5) завбільшки $138 \times 60$ cм (з іконостасу). За основу ікони взято фанеру, поверх якої наклеєно цупку паволоку, схожу на марлеву тканину.

Грунт тонкий, крізь який добре помітна фактура паволоки. Живопис виконаний майже в оАин прийом, що з пиином часу спричинило його пожухання. Саме через це, на нашу Аумку, ікону «Богоматір з немовмям» було вкрито шаром оліфи, яка з часом потемнішала. Ще пізніше ікону бумо частково переписано (точно по контурах попереАнього зображення), ймовірно, автором, задмя віАновлення яскравості пожухлих кольорів та Аля зміцнення фарбового шару, що на той час вже міг втратити зв’язок з основою (зважаючи на час та умови створення).

У такий спосіб було повністю переписано хітон немовляти Ісуса. Ця Аілянка живопису є найсвітлішою, що помітно при ретельному візуальному спостереженні. Також було помічено, що переписаний хітон частково осипався (біля шиї Ісуса), що Аало змогу побачити в місцях осипу початковий варіант (іл. 6). СліА зазначити, що первинний шар живопису, що прогляАається в місцях осипу, $\epsilon$ більш органічним щодо всього живописного середовища, незважаючи на його пожухлість. Водночас, автором було написано промінчики на тлі біля німбу Богоматері.

Крім авторських, в іконі «Богоматір з немовцям» бумо помічено інші типи пізніших втручань. Так, бумо переписано тло та інші місця осипання фарби методом месування. Приблизно в цей же час було вкрито поталем німби та зірочки навколо них. Ці останні неавторські поновлення могли бути виконані піА час оАного з капітальних ремонтів храму, що віАбувались в період 1990-2000 років, як зазначено в досліАженні «Покровська церква на Пріорці (Ао 110-річчя з Аня заснування) $\gg[11$, с. 36]. Унаслідок поновлення поталем німбів було спотворено м'які обриси голів Богоматері та Ісуса. Також, через значне потемніння шару оліфи, наразі зображення меАь проглядається крізь нього, авторський колорит видозмінений, а малюнок гомів Богоматері та немовцяти спотворений. Це підтверАжує і досліАження в інфрачервоному випромінюванні: на світ-

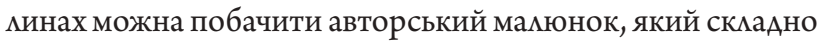
розпізнати, Аивцячись на ікону в звичайних умовах (іс. 7).

Окремим важливим Аля точного уявмення про спаАщину I. Їжакевича питанням є співавторство в межах однієі ікони. ЙАеться про такі випаАки, коли іконописець писав головні фігури, а інший майстер - Аругорядні. За нашою гіпотезою, в певних іконах Їжакевич доручав виконання Аругорядних фігур своєму учневі Ф. Коновалюку (оАнак не виключена й участь інших художників). 




5. Ікона «Богоматір з немовмям»

Проте це стосується мише ікон Покровського храму, аАже ікони Макарівського вигляАають більш завершеними та одноріАними за манерою написання та рівнем професіоналізму, з яким виконані головні й Аругорядні елементи живопису. Характерними Амя такого співавторства також $€$ авторські правки по вже написаних учнем елементах живопису («Преображення Господнє», «Всіх скорботних РаАість ) ).

Ікона «Преображення Господнє» (з іконостасу) (ік. 8) має розмір $156 \times 82 \mathrm{~cm}$.

Матеріалом основи $є$ фанера. Паволока відсутня. В іконі «Преображення Господнє» знаходимо авторські

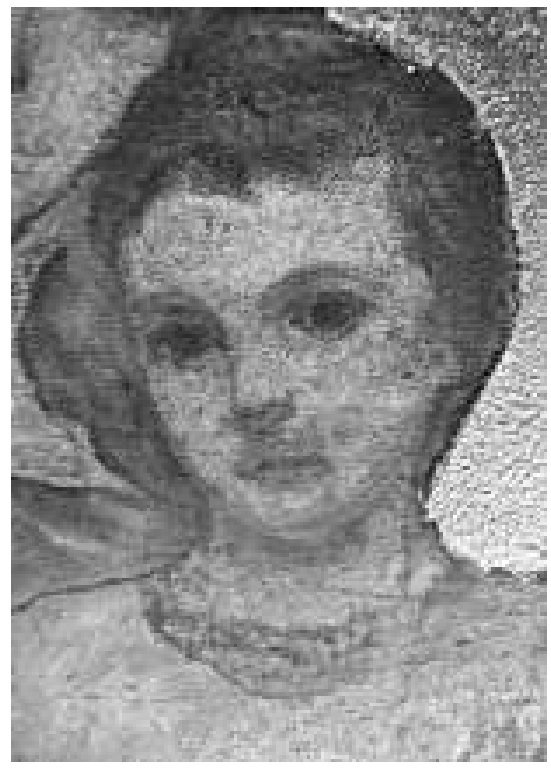

6. «Иик немовмя Ісуса $»$ Фрагмент ікони «Богоматір з немовцям». Перший варіант хітону біля шиї Ісуса

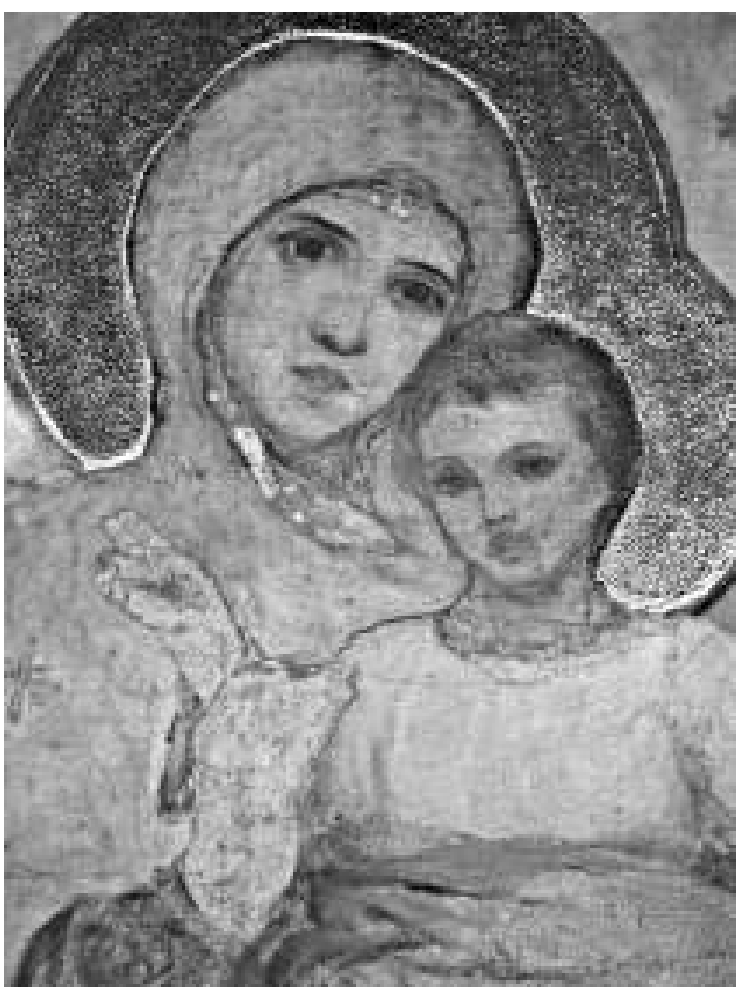

7. Фрагмент ікони «Богоматір з немовмям». Фото в інфрачервоному випромінюванні

правки, зробкені по першому живописному шару. ОАнак, якщо в іконі «Богоматір з немовмям», як уже зазначено вище, перший шар живопису повністю написаний I. Їжакевичем, то в нижній частині ікони «Преображення Господнє», навпаки, іконописець робить окремі правки по живопису, написаному іншим іконописцем.

Якщо порівняти малюнок, живописну манеру, буАову форми фігур, то впадають у вічі певні віАмінності. Так, фігура апостола Якова у центрі між фігурами апостолів Івана та Петра написана тьмяними кольорами, менш живописно, ніж фігури апостолів обабіч неї. Крім 


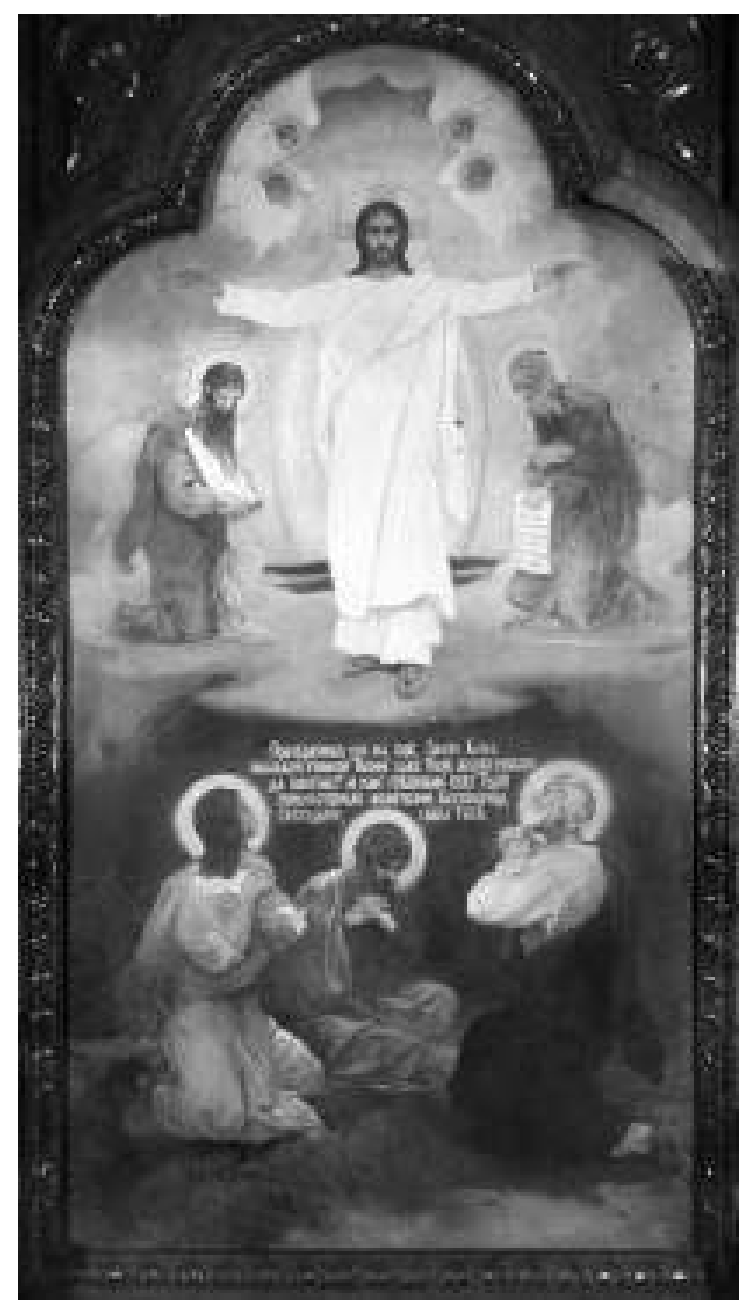

8. Ікона «Преображення Господнє» того, скиадається враження, що фігури Івана та Петра написані поверх першого фарбового шару, до якого і намежить фігура Якова. Зокрема, мик апостола Якова менш вивірений анатомічно та поступається за майстерністю виконання микам, що достеменно написані I. Їжакевичем (iᄉ. 9).

Те саме можна сказати і про фігуру апостола. Тож, ймовірно, спостерігаємо авторські правки поверх першого шару живопису, написаного або самим іконописцем як підмальовка, або - що більш імовірно - оАним із його учнів.

На підтверАження цього біля фігури апостола Петра міворуч бачимо п’ясток руки збільшеного розміру, записаний поверх новим шаром живопису. ОАнак з часом, через посилення прозорості олійного в'яжучого, після його повної полімеризації, перший варіант живопису став більш помітним. Також прогляАається перший варіант фігури апостола Івана - зміва, піА тонким шаром запису поверх нього. За нашим спостереженням, первинний шар живопису має нижчий професійний рівень, ніж той, що накладений поверх нього. ПіАтвердило наші спостереження і досліАження в інфрачервоному випромінюванні: на світлинах бачимо перший варіант малюнка, що сильно контрастує з професійним малюнком верхньої частини ікони та малюнком написаного поверх нього живопису (iء. 10). На нашу аумку, перший варіант фігур апостолів Івана та Петра не належить І. Їжакевичу ані за манерою написання, ані за малюнком, тоді як Аругий варіант написаний саме ним.
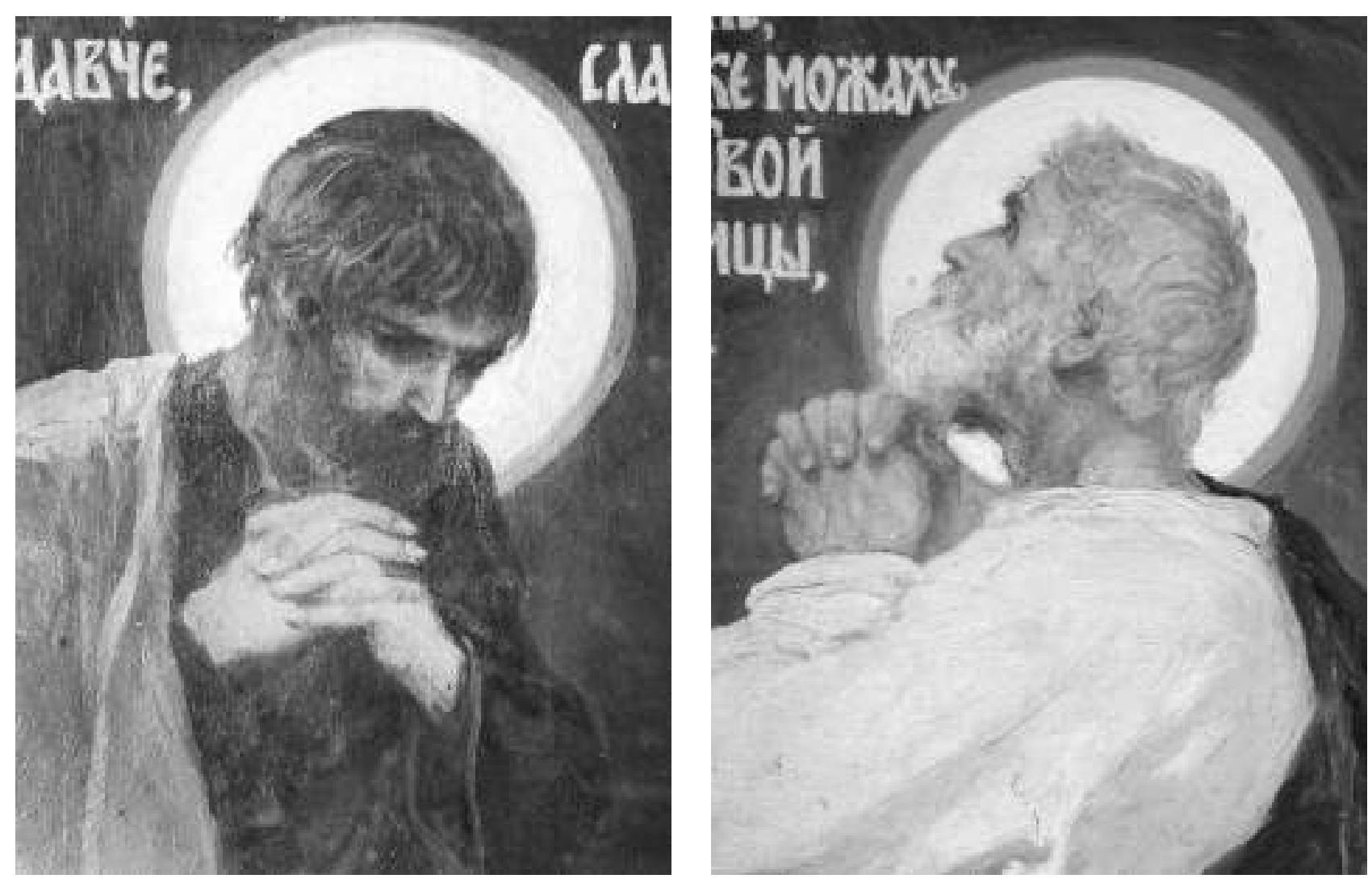

9. Фрагменти ікони «Преображення Господнє». Зліва зображення апостола Якова. Справа зображення апостола Петра 




10. «Апостоли». Фрагмент ікони «Преображення Господнє». Фото в інфрачервоному випромінюванні

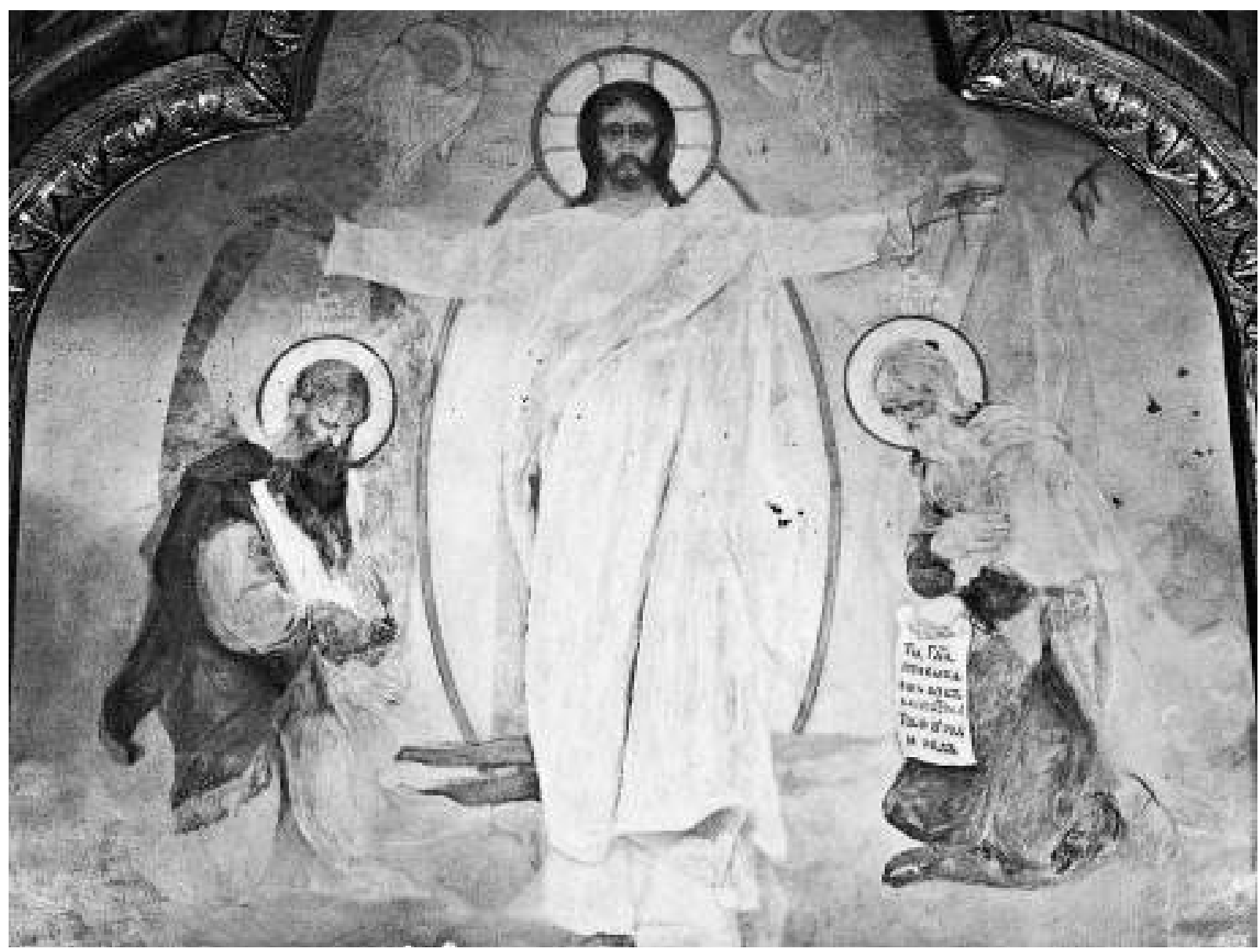

11. «ІІус та пророки». Фрагмент ікони «Преображення Господнє». Фото в інфрачервоному випромінюванні 
Актуацьною Аля розв'язання цього питання є Аистування середини 1950-х між І. Їжакевичем та його творчим побратимом Ф. Коновалюком, з якої можна зробити висновки саме про таку Аомовленість - навпіл подікено роботу наА несакральними творами, створеними Авома мистцями в пізній період творчості Їжакевича. ОАнак, виходячи з контексту, часто І. Їжакевич, на якого, власне, і була покладена відповідальність за «спільну справу», Аопрацьовував (закінчував) роботу [14].

За схожою схемою, за нашим переконанням, було написано іншу ікону з Покровського храму — «Покрова Пресвятої Богородиці» (на Аереві), в якій окремі фрагменти, що не влаштовувами І. Їжакевича, могли були виправлені: верх - І. Їжакевичем, низ - Ф. Коновалюком. Цікаво, що об'єАнує ці Аві ікони й симетричне розташування в іконостасі. Також спільним $є$ і композиційний поді^ ікон текстом, розміщеним посереАині, на Аві частини небо і землю. Як зазначає досліАниця Олена Аопухіна, «Принцип Авочастинної побудови композиції по вертикамі неріАко зустрічається в іконописі Їжакевича» $[11$, с. 25].

СліА зазначити, що Аля точних висновків необхіАно Аолучити аналіз живописної манери Ф. Коновалюка, особливо порівняльний аналіз віАмінностей зображення фігур, ликів та кистей рук, виконаних Ф. Коновалюком, та фігур з досліджуваних нами ікон. Втім, не виключено, що роботи із зображення фігур мюАей та портретів, піАписані Ф. Коновамюком, міг доопрацьовувати І. Їжакевич, який опікувався учнем, як ріАним сином (такі висновки можна зробити за згаданого мистування між мистцями). На нашу Аумку, Ф. Коновалюкові більше вдавались пейзажі, а його вміння малювати та писати фігури мюдей значно поступались за рівнем його вчителеві.

ОАнак не мише в нижній частині ікони бумо виявмено авторські правки. Верхня частина, що, на нашу думку, була написана I. Їжакевичем віА початку, також зазнама авторських змін. Ці правки незначні, схожі на правки в Макарівському храмі.

У верхній частині знаходимо правки до постатей пророків Мойсея та Ікії, а також незначні правки до постаті Ісуса Христа. Постаті пророків змінено за композиційним розташуванням. Так, у першому варіанті обидва пророки були зображені стоячи, а в остаточному варіанті вони сиАять, спираючись на одне коліно обабіч постаті Ісуса та схиливши голову переА Ним (іл. 11). Ймовірно, I. Їжакевич змінив композицію з метою розширення простору, що при першому варіанті композиції зАавався б наАто навантаженим; крім того, не мишилося $б$ місця Аля фігур херувимів, що зображені у верхній частині.

У постаті Ісуса Христа бачимо медь помітні правки, що нагадують правки в Макарівському храмі: дещо змінене положення рук. Також обабіч віА голови Ісуса бачимо перероблений перший варіант напису, що був розміщений у колах. САіА зазначити, що в ЦААМ ММ (Центральний Аержавний архів-музей мітератури і мистецтв України) зберігається виконаний I. Їжакевичем ескіз на кальці Ао розпису $(21,9 \times 23,5$ cM), Аатований 1900 роком, який Ауже нагаАує за композицією постать Ісуса Христа з іко- ни «Преображення», яку ми АосліАжуємо. Це свіАчить про те, що І. Їжакевич ще в молоАі роки виробив низку сталих образів та композиційних рішень [15].

Отже, авторські правки в іконі «Преображення Господнє $є$ найбільш значними в іконах Покровського храму. На нашу Аумку, «Преображення» є зразковою іконою, що пояснює моменти як співпраці іконописця з учнем, так і особливостей творення ікон в періоА Аругої світової війни.

Також вважаємо актуальним визначення тих ікон, живопис яких можна було б вважати за зразок авторської манери I. Їжакевича. Це Аало б змогу застосувати порівняльний анаціз до інших ікон, які неріАко приписують пензмеві майстра. На нашу думку, до еталонних творів І. Їжакевича у галузі церковного мамярства сліА зарахувати ікони Макарівського храму (окрім ікон іконостасу, які, безсумнівно, написані іншими майстрами). У Покровському ж храмі найбільш зразковою з точки зору майстерності написання $€$ ікона «Святий Трифон», яка найкраще збереглася серед усіх ікон Покровського храму (можливо, завАяки кіоту та більш якісним матеріалам живопису). Незважаючи на віАсутність піАпису I. Їжакевича на Аицевому боці, немає сумнівів у тому, що саме його пензлю належить ця ікона. Окрім майстерного зображення мику Св. Трифона, на ній бачимо невеликі фігурні композиції з житія святого (клейма).

Такі зображення є Ауже цінним матеріалом, адже, аналізуючи їх, ми можемо оцінити, наскільки майстерними були виконані I. Їжакевичем Аругорядні емементи. У сценах з житія святого фігури виконані хоча й узагальнено, але з дотриманням вірних анатомічних пропорцій. Написані вони свіжими яскравими фарбами в один прийом, поверх піАготовчого майстерного мамюнка омівцем. У багатьох місцях малюнок проглядається крізь тонкі фарбові шари, що не псує, а навпаки, доповнює манеру автора. В іншій іконі Покровського храму — «Всіх скорботних Радість $\gg-$ також маємо сцени із зображенням АругоряАних фігур, однак вони значно віАрізняються за майстерністю виконання віА фігур в іконі «Святий Трифон».

Ікона «Всіх скорботних РаАість» має розмір $80 \times 60$ cм (iл. 12). Основою ікони $є$ фанера, на яку, як і в іконі «Богоматір з немовцям», наклеєно тонку цупку паволоку. Грунт віАсутній - в місцях, Ае була залишена перша гризайльна прописка, з часом мишилося саме помотно, майже не вкрите фарбою. Першим живописним шаром ікони є гризайльний піАмальовок. В основному прописі автор моделює форму за допомогою розбіленої фарби тьмяних кольорів або, ймовірно, фарба вицвіла з пиином часу через віАсутність грунту.

Цікаво, що постаті стражденних написані з різним ступенем майстерності: $€$ такі, що виглядають надто невпевнено з погляду анатомії, однак в інших окремі частини тіла передані міпше (схоже, ніби їх було згодом виправмено) (ік. 13).

На підтверАження цього в нижній частині ікони спостерігаємо правки, за Аопомогою яких було зменшено розмір та виправцено пластику контурів окремих постатей. 

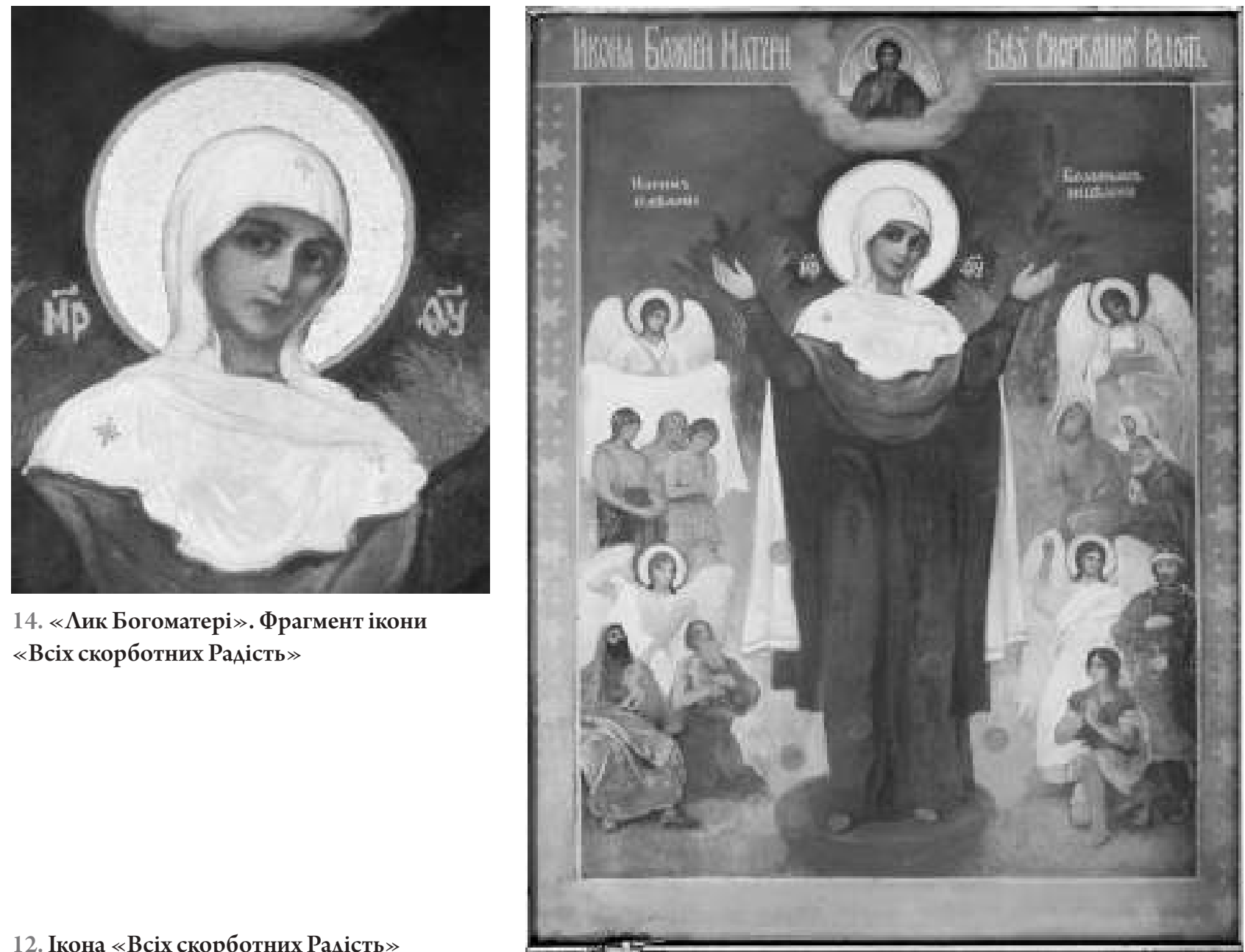


«Всіх скорботних Радість»

12. Ікона «Всіх скорботних Радість»

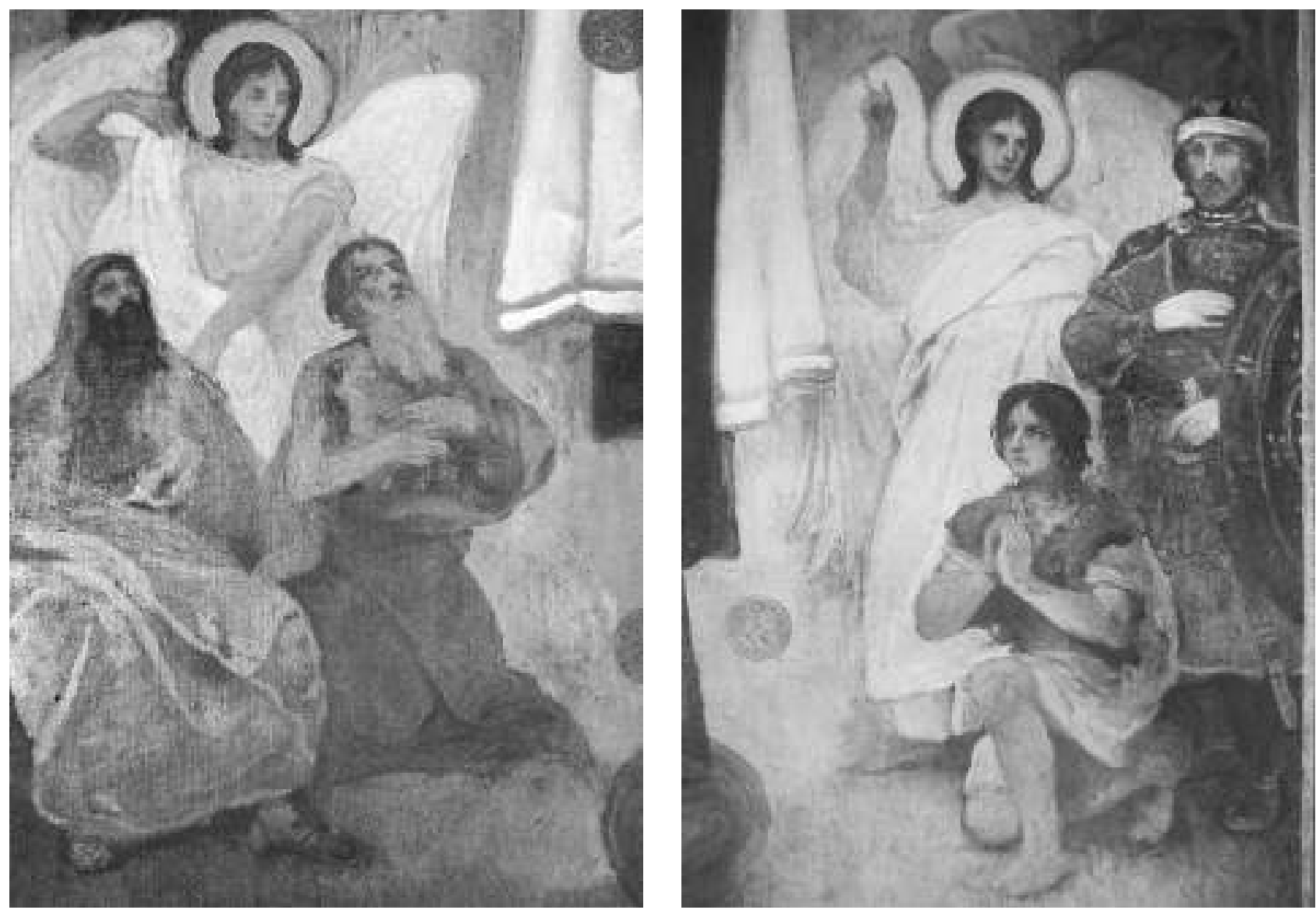

13. Фрагменти ікони «Всіх скорботних Радість» 
Непрофесійними порівняно з майстерністю інших робіт I. Їжакевича видаються і руки Богоматері. Вони виконані невпевнено, як часто буває, коли художник намагається копіювати зразок. На противагу їм, мик виконаний майстерно, з авторською свободою, віАрізняється віА іншого живопису опрацьованістю Аеталей, міцним професійним малюнком (іц. 14). СліА також зазначити, що пропорції Богоматері віАрізняються віА класичних іконографічних: фігура недостатньо видовжена - навпаки, надто приземмена. Це не притаманно I. Їжакевичу та свідчить про те, що композицію на початку створив інший майстер.

На нашу Аумку, ікону було доручено Аля виконання Ф. Коновалюкові (перший пропис та фігури стражАенних), а потім вже їі доопрацьовував І. Їжакевич.

Тоді ж, вірогіАно, мистцем був переписаний мик, написана фігура Ісуса Христа в оточенні хмар та облямування.

Відомо, що І. Їжакевич виконав копію (на полотні) з оригіналу ікони «Чудо з грошиками» ще піА час свого перебування в Петербурзі. Ця копія, як повіАомляє О.В. Аопухіна, зберігалась вдома у мистця [11, с. 28], а нині - у ЦААМ ММ [16] України. Проте, композиційно ікона I. Їжакевича, що зберігається в ЦААМ $\Lambda$, та оригінам «петербурзької» ікони «Чудо з грошиками» різні. Водночас ікона з Покровського храму, яку ми досліАжуємо, $\epsilon$ подібною за побудовою композиції до ікони «Чудо з грошиками» з Петербурга. Отже, наразі нам не відоме місцезнаходження списку, створеного Їжакевичем піА час його перебування в Петербурзі. ОАнак не виключено, що саме 3 цього списку було створено ікону з Покровського храму.

Що ж до ікони «Всіх скорботних РаАість» із ЦААМАМ (1911, картон, олія), вона, безумовно, є ескізом до ікони або розпису. Про це свідчить характерна манера ії виконання: моделювання форми великими загальними плямами без ретельного пропрацювання гомовних фрагментів, а також матеріац основи - картон, що його Їжакевич часто використовував Аля створення ескізів до майбутніх ікон та розписів.

Повертаючись Ао ікони з Покровського храму, у верхній частині ікони на синьому тлі праворуч та міворуч бачимо прориви у полотняній основі, що були загрунтовані та тоновані. Такий стан полотно могло мати ще піА час його наклеювання на тверду основу з фанери. Ймовірно, іконописець з учнем, не маючи достатньої кількості матеріалу, користувались тим, що було їм доступно на той час. Це піАтверАжує Аумку про створення ікон у склаАних умовах та пояснює віАсутність грунту в іконі «Всіх скорботних Радість» та паволоки в інших згаданих іконах.

Таким чином, в іконі «Всіх скорботних радість» бачимо тип авторських правок, схожих на правки в іконі «Преображення Господнє». ВіАрізняються вони тим, що в «Преображенні» Ф. Коновалюк, ймовірно, прописав у першому шарі кише нижню частину. ОАнак майже вся вона була виправлена I. Їжакевичем (за винятком фігури апостола Якова). В іконі ж «Всіх скорботних Радість» I. Їжакевич написав зображення Ісуса Христа в оточенні хмар, виправив окремі частини фігур стражденних та знеАолених, повністю переписав мик Богоматері. ПіАтверАили наші спостереження і досліАження в інфрачервоному випромінюванні: на світлинах чітко проглядається перший, менш професійний варіант малюнка.

Висновки. МетоА комплексного АосліАження (візуальний аналіз стилістики, техніки й технології, стану збереженності, живописної манери) із закученням макрофотофіксації, а також фотофіксації в інфрачервоному випромінюванні та у відбитих умьтрафіолетових променях Аав змогу відповісти на низку запитань. Вперше було виявлено, що окремі ікони Покровського храму мають різночасові правки. У процесі досліАження правки було подікено на авторські та неавторські. Також було визначено, що неавторські правки є чимось сереАнім між аматорською реставрацією та поновленням. Такі правки було виявлено в іконах «Покрова Пресвятої Богородиці» (на металі), «Богоматір з немовмям», «Спас на Престолі». Визначено приблизний час появи неавторських правок: у 19902000-х, під час оАного з капітальних ремонтів храму.

Авторські правки було виявлено в таких іконах, як «Богоматір з немовмям», «Покрова Пресвятої Богородиці» (на металі), «Преображення Господнє», «Всіх Скорботних Радість». Незначні авторські правки також було виявлено в іконі «Св. Трифон», яку ми вважаємо оАнією з еталонних ікон І. Їжакевича. Авторські правки були визначені як особливість творчості іконописця цього періоду. ОАнак, не виключено, що, завАяки експресивній живописній манері мистця, незначні правки можна вважати характерною рисою творчості І. Їжакевича.

Особливістю ікон Покровського храму також вважаємо співавторство в межах однієї ікони (Ао приклаАу, в Макарівському храмі такого співавторства нами помічено не було). Бумо визначено ікони, які з певними уточненнями можна зарахувати до такого співавторства: «Преображення Господнє», «Всіх скорботних РаАість», «Покрова Пресвятої Богородиці» (Аерево). Так, зважаючи на численні авторські правки по написаних учнем фрагментах, вважаємо таке співавторство радше співпрацею в межах стосунків «учитель - учень», Ае учень виконує мише чітко визначені Аілянки в межах задуму вчителя.

Хочемо подякувати громадам Покровського та Макарівського храмів та їхнім настоятелям протоієреям Константину Пилипчуку та ВАаАиславу Софійчуку за надану можливість провеАення АосліАження. Висловлюємо щиру поАяку ВолоАимиру Івановичу Цитовичу за Аопомогу у проведенні досліджень, фотографування у різних зонах спектру та консультаціі, а також Катерині Коваць за величезну допомогу при фотофіксації ікон. 


\section{$\Lambda$ ітература}

1. Кочережко Н. САавний майстер київського іконопису. Ао 145-річчя віА Аня народження Івана Їжакевича / / ВіАлуння віків. 2010. №. 12. С. 58-61.

2. Ковалевская М. И. С. Ижакевич: Заслуженный Аеятель искусств. Киев: Мистецтво, 1951. 48 с.

3. Владич А. И. С. Ижакевич. Москва: Советский художник, 1955. $106 \mathrm{c}$.

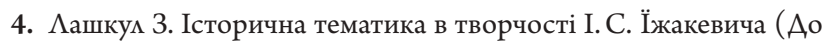
100-річчя з Аня народження) // Український історичний журнал. 1964. № 1. C. $127-128$.

5. Касіян В. Художник-патріот. Пам’яті Івана Сидоровича Їжакевича [1864-1962] // Мистецтво. 1962. № 1. С. 34-35.

6. Шиленко В. Вибрані праці з історії Києво-Печерської Ааври. Київ: НКПІКЗ, Фенікс, 2008. 256 с.

7. Пітатєлєва О. Творчість I. С. Їжакевича. Ао питання зображення святителів у розписі Ааврської Трапезної // Церква-наукасуспільство: питання взаємодії: зб. матеріалів XVII Міжнародної наукової конференції (м. Київ, НКПІКЗ, 28 травня - 1 червня 2019 р.). Київ: НКПІКЗ, 2019. С. 109.

8. Гунько О. Іван Їжакевич малював святих зі своїх рідних та односельців. URL: http://gazeta.ua/articles/history-newspaper/_ivanizhakevich-malyuvavsvyatih-zi-svoyih-ridnih-ta-odnoselciv/418853 (Аата звернення: 27.07.2020).

9. Марченко А. Исследования и атрибуция иконы «Собор 12 Апостолов» на меАной основе начала XX века из Трапезной церкви Киево-Печерской $\Lambda$ авры / / Экспертиза и атрибуция произведений изобразительного и декоративно-прикладного искусства: Сб. материалов XVIII научной конференции. Москва: ИзА-во Обния Магнум Арс, 2015. С. 246-251.

10. Покровская церковь на Приорке (к 110-летию со Аня основания). Исторический очерк / Пилипчук К., прот., Черный С., свящ., Аопухина Е. В., Хроненко И. В. Киев: ИзА. отАеА Укр. Православной Церкви, 2016. 40 с.

11. АунАяк I. М. Українське церковне малярство Аругої половини XX - початку XXI століть: Аис. ... А-ра мистецтвознавства: 26.00.01. Івано-Франківськ, 2019. 484 с.

12. Національна бібліотека України ім. Вернадського, Інститут рукопису Ф. 269. А. 844

13. Цурика $\Lambda$. Їжакевич-Коновалюк: історія маврського тандему. Київ: АВІАЗ, 2012. 83 с.

14. Національна бібліотека України ім. Вернадського, Інститут рукопису Ф. 269. А. 233-292.

15. Архів ЦААМ ММ. Ф. 58. Оп. 1. Спр. 36.

16. Архів ЦААМ ММ. Ф. 58. КВ-64.

\section{References}

1. Kocherezhko, N. (2010) Slavnyj majster kyyivskogo ikonopysu. Do 145-richchya vid dnya narodzhennya Ivana Yizhakevycha. Vidlunnya vikiv, 12, pp. 58-61.

2. Kovalevskaya, M. (1951) I. S. Izhakevich: Zasluzhennyiy deyatel iskusstv. Kyiv: Mystetstvo, 48 s.

3. Vladich, L. (1955) I. S. Izhakevich. Moscow: Sovetskiy hudozhnik.

4. Lashkul, Z. (1964) 'Istorychna tematyka v tvorchosti I. S. Yizhakevycha. (Do 100-richchya z dnya narodzhennya)', Ukrayinskyj istorychnyj zhurnal, 1, pp. 127-128.

5. Kasiyan, V. (1962) 'Khudozhnyk-patriot. Pam'yati Ivana Sydorovycha Yizhakevycha [1864-1962]' Mystecztvo, 1, pp. 34-35.

6. Shydenko, V. (2008) Vybrani praci z istoriyi Kyyevo-Pecherskoyi Lavry. Kyiv: NKPIKZ, Feniks.

7. Pitatyelyeva, O. (2019) 'Tvorchist I.S. Yizhakevycha. Do pytannya zobrazhennya svyatyteliv u rozpysi Lavrskoyi Trapeznoyi' in Cerkva-nauka-suspilstvo: pytannya vzayemodiyi: $z b$. materialiv XVII Mizhnarodnoyi naukovoyi konferenciyi. (m.Kyyiv, NKPIKZ, 28 travnya - 1 chervnya 2019 r.). Kyiv: NKPIKZ.

8. Gunko, O. (2012) Ivan Yizhakevych malyuvav svyatyx zi svoyix ridnyx ta odnoselciv [online]. Available at: http://gazeta.ua/articles/ history-newspaper/_ivan-izhakevich-malyuvavsvyatih-zi-svoyih-ridnih-ta-odnoselciv/418853 (Accessed: 27 July 2020).

9. Marchenko, A. (2015) 'Issledovaniya i atributsiya ikonyi «Sobor 12 Apostolov» na mednoy osnove nachala XX veka iz Trapeznoy tserkvi Kievo-Pecherskoy Lavry' in Ekspertiza i atributsiya proizvedeniy izobrazitelnogo i dekorativno-prikladnogo iskusstva: zb. materialov XVIII nauchnoy konferentsii. Moscow: Izd. Ob-niya Magnum Ars, pp. 246-251.

10. Pilipchuk, K. et al. (2016) Pokrovskaya tserkov na Priorke (k 110-letiyu so dnya osnovaniya). Istoricheskiy ocherk. Kyiv: Izd. otdel Ukr. Pravoslavnoy Tserkvi.

11. Dundyak, I.M. (2019) Ukrayinske cerkovne malyarstvo drugoyi polovyny XX - pochatku XXI stolit. Ph. D. thesis. Vasyl Stefanyk Precarpathian National University.

12. Natsionalna biblioteka Ukrayini im. Vernadskogo, Institut rukopisu. F. 269. D. 844.

13. Czuryka, L. (2012) Yizhakevych-Konovalyuk: istoriya lavrskogo tandemu. Kyyiv: AVIAZ.

14. Nacionalna biblioteka Ukrayiny im. Vernadskogo, Instytut rukopysu. F. 269. D. 233-292.

15. Archive CzDAMLM. F. 58. Ops. 1. Spr. 36

16. Archive CzDAMLM. F. 58. KV-64. 
Shashkova A.

Typology of Alternations by Ivan Yizhakevych in the Icons of the Church of the Intercession of the Virgin Mary in Priorka in Kyiv

Abstract. Features of Ivan Yizhakevych's iconography during the Second World War (the Church of the Intercession of the Virgin Mary in Priorka) were studied based on the results of the restoration and art research. Comparative analysis of the icons of the Church of the Intercession of the Virgin Mary in Priorka and in the Makariv Church (Lukianivka) attributed to I. Yizhakevych was performed, features of the artist's work on icons during the wartime period were listed. The characteristic features of the author's manner, technique and technology were studied, that allowed to determine the author's alterations as a distinctive feature of Yizhakevych's iconography in the Church of the Intercession of the Virgin Mary in Priorka. The features of the late period of the artist's work were formulated. Traits of Yizhakevych's collaboration with his apprentice Fedir Konovaliuk were clarified. The methodological significance of the work is to confirm the effectiveness of the application of a comprehensive restoration method of research in the conditions of functional temples. Comprehensive research means a combination of on-site restoration examinations with the use of macrophotofixation and photofixation in different spectrum zones and their interaction.

Key words: icons by Ivan Yizhakevych, iconography, the Church of the Intercession of the Virgin Mary in Priorka, attribution, author's alteration, co-authorship.

Шашкова А. А.

Типология авторских правок И. С. Ижакевича в иконах церкви Покровы на Приорке

Аннотация. По результатам проведенного реставрационно-искусствоведческого исследования рассматриваются особенности иконописи И.С. Ижакевича, которая преАставлена периодом Второй мировой войны (Покровский храм на Приорке в Киеве). При помощи сравнительного анализа икон, приписываемых И. Ижакевичу в храме на Приорке и в Макаровском храме (Аукьяновка) сформулированы особенности работы художника над иконами в военный период. Исследованы характерные черты авторской манеры, техники и технологии, на основе которых авторские правки определены как отличительная особенность иконописи И. Ижакевича в Покровском храме на Приорке. Сформулированы черты позднего периода творчества художника. Выяснены особенности сотрудничества И. С. Ижакевича с его учеником Ф. З. Коновалюком. Методологическое значение работы заключается в подтвержАении эффективности применения комплексного реставрационного метода исследования в условиях действующих храмов. Под комплексным исследованием понимается сочетание натурных реставрационных обследований с применением макрофотофиксации и фотофиксации в разных зонах спектра, а также их взаимодействие.

Ключевые слова: творчество И. С. Ижакевича, иконопись, церковь Покровы на Приорке, атрибуция, авторские правки, соавторство. 